\title{
Review
}

\section{Antimicrobial peptide defensin: Identification of novel isoforms and the characterization of their physiological roles and their significance in the pathogenesis of diseases}

\author{
By Yasuhiro YAmaGuCHI ${ }^{* 1, \dagger}$ and Yasuyoshi OUCH ${ }^{* 1}$
}

(Communicated by Kumao Toyoshima, M.J.A.)

\begin{abstract}
Defensins comprise a family of cationic antimicrobial peptides containing a specific six-cysteine motif. Their contribution to the host defense against microbial invasion and the control of normal flora have been previously described. Some of the $\beta$-defensin isoforms are predominantly expressed in the epididymis and showed a region-specific expression pattern in the epididymis, which thus suggested that these isoforms may possess epididymis-specific functions in addition to antimicrobial activities. A sequence variant of the $\beta$-defensin 126 gene has been shown to be associated with reductions in the human sperm function, thus supporting this hypothesis. Furthermore, defensins have the capacity to chemoattract immune cells and induce the secretion of inflammatory cytokines. Mice expressing human neutrophil $\alpha$-defensin showed more severe lung injuries after the aspiration of acidic contents than did control mice. Recent investigations regarding copy number variations of human defensin genes also suggest the significance of defensin in the pathogenesis or the worsening of chronic obstructive pulmonary diseases, sepsis and psoriasis.
\end{abstract}

Keywords: defensin, antimicrobial peptide, epididymis, cytotoxicity, lipopolysaccharide, inflammation

\section{Introduction}

Host defense against infection is a crucial function for all life forms. While vertebrates develop acquired immunity, insects and many other species possess only innate immunity, which is a congenital immune system. Antimicrobial peptides are major components of the innate immune system. More than 400 antimicrobial peptides have been discovered across various species, from plants to mammals. ${ }^{1)}$

*1 Department of Geriatric Medicine, Graduate School of Medicine, The University of Tokyo, Tokyo, Japan.

$\dagger$ Correspondence should be addressed: Y. Yamaguchi, Department of Geriatric Medicine, Graduate School of Medicine, The University of Tokyo, 7-3-1 Hongo, Bunkyo-ku, Tokyo, 1138655, Japan (e-mail: yamayasu-tky@umin.ac.jp).

Abbreviations: HNP: human neutrophil peptides; TAP. tracheal antimicrobial peptide; hBD: human $\beta$-defensin; LPS: lipopolysaccharide; mBD: mouse $\beta$-defensin; PCR: polymerase chain reaction; RT: reverse transcription; CNV: copy number variation; S. aureus: Staphylococcus aureus; S. typhimurium: Salmonella typhimurium; SAPG11: sperm-associated antigen 11; BALF: bronchoalveolar lavage fluid; ARDS: acute respiratory distress syndrome; COPD: chronic obstructive pulmonary diseases.
Historically, investigation on antimicrobial peptides began with the following question: how are insects protected from microorganisms, without having antibodies or T cells?2) In 1981, the sequences of two antimicrobial peptides, cecropins $\mathrm{A}$ and $\mathrm{B}$, were identified in moths. These were the first reported peptides that showed selective toxicity against bacteria. ${ }^{3)}$

Magainin in Xenopus is the first antimicrobial peptides reported in vertebrates. ${ }^{4}$ ) The finding that Xenopus used in the laboratory had no wound infection or inflammation despite abdominal surgery for extraction of their oocytes in a non-sterile environment led to this discovery. ${ }^{4)}$

Lehrer et al. detected three small antibiotic peptides, human neutrophil peptides (HNP) -1, -2, and, -3 , in the extracts obtained from neutrophil granules and referred to them as defensins.5) Subsequently, a cysteine-rich antimicrobial peptide was identified in the bovine respiratory tracts, and this peptide was named tracheal antimicrobial peptide (TAP) ${ }^{6}{ }^{6}$ TAP and other antimicrobial peptides 


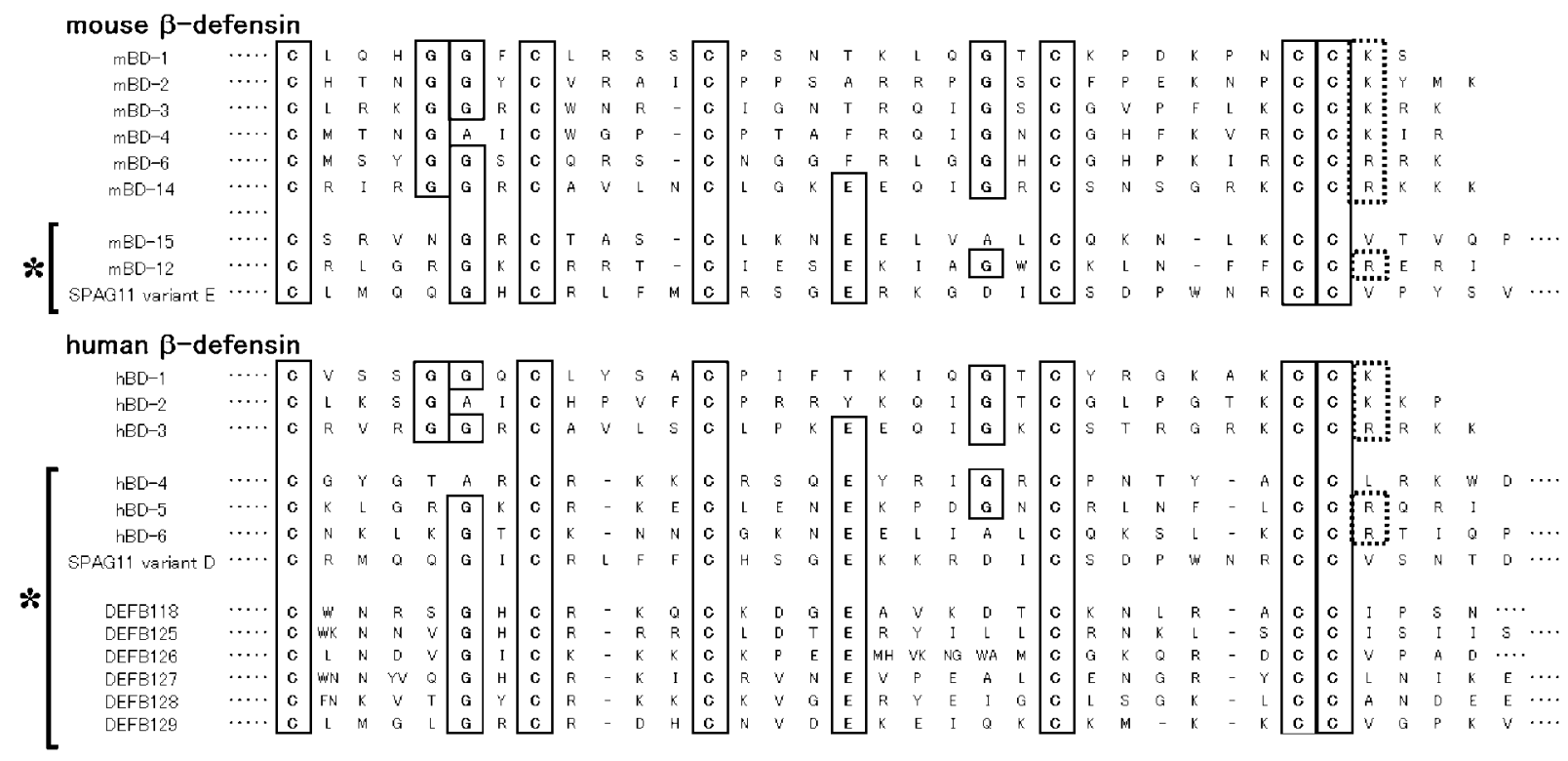

Fig. 1. The amino acid sequences of human and mouse $\beta$-defensins. The partial amino acid sequences of representative human and mouse $\beta$-defensin isoforms are shown, including the six-cysteine motif. The boxes indicate conserved amino acid residues. The dashed box indicates the conserved basic amino acid residue. ${ }^{*}$ indicates the defensin isoforms predominantly expressed in the epididymis.

subsequently discovered from bovine neutrophils have structural and functional features similar to those of HNPs, although their six-cysteine motif differs from that of HNP. HNPs were classified as $\alpha$ defensin, and TAP was classified as $\beta$-defensin. ${ }^{7)}$ In addition, $\theta$-defensin isolated from rhesus macaque leukocytes was a unique antimicrobial peptide. ${ }^{8)} \theta$ Defensin is composed of two short peptides ligated by three disulfide bonds. However, the expression of $\theta$ defensin has not been detected in humans.

In this review, we will discuss the history of defensin investigation, including the authors' own studies, with a focus on the genome-wide identification of novel $\beta$-defensin genes, the peculiar features of epididymis-predominant $\beta$-defensin isoforms, and the potential pathogenic significance of defensins in human inflammatory diseases.

\section{Discovery of human $\beta$-defensin-1, -2 , and -3}

In humans, $\alpha$-defensins can be grouped into neutrophil defensins and enteric defensins. Neutrophil defensins comprise HNP-1, -3, and -4, and enteric defensins comprise HD-5 and $\left.-6 .{ }^{9}\right)$

Human $\beta$-defensin (hBD)-1 was first identified by large-scale extraction of plasma peptides from human hemofiltrate (Fig. 1). ${ }^{10)} \mathrm{hBD}-1$ is mainly expressed in urogenital tracts such as the kidney, but its expression has also been detected in the pancreas, lung, skin, and intestine (Table 1). ${ }^{11)-13)}$
The discovery of hBD-2 attracted a great deal of interest as an inducible antimicrobial peptide. Schröder et al. searched for novel antimicrobial peptides in psoriasis scale, which resulted in the isolation of hBD-2 (Fig. 1). ${ }^{14)}$ hBD-2 is expressed in the skin, lung, and trachea, and widely expressed in other tissues (Table 1). ${ }^{14), 15)}$ Lipopolysaccharide (LPS) induces hBD-2 expression. ${ }^{14)}$

Subsequently, hBD-3 was isolated from human skin (Fig. 1). hBD-3 has potent antimicrobial activity against gram-positive cocci independent of the environmental salt concentration. ${ }^{16)} \mathrm{hBD}-3$ is expressed in the skin, esophagus, trachea, and placental membrane, and widely expressed in other tissues (Table 1). ${ }^{16)-18)}$

\section{The characteristics of mouse $\beta$-defensin-3, $-4,-6$, and -14}

2-1. Mining of the human and mouse genomes to search for novel $\boldsymbol{\beta}$-defensin genes. After the identification of hBD-1 and hBD-2, mouse $\beta$ defensin (mBD)-1, $-2,-3$, and -4 were identified as mouse $\beta$-defensin genes homologous to hBD-1 or hBD-2. ${ }^{19)-23)}$ Genomic analysis of $\alpha$ - and $\beta$-defensin genes revealed that defensin genes comprise a gene cluster spanning about $450 \mathrm{~kb}$ on chromosome 8 (Fig. 2). ${ }^{24)}$ Many novel $\beta$-defensin isoforms were identified using an approach involving the mining of the human and mouse genomes. ${ }^{17), 25)-27)}$ Defensins 
Table 1. The representative sites of $\beta$-defensin expression

\begin{tabular}{|c|c|c|}
\hline & The representative sites of predominant expression & references \\
\hline \multicolumn{3}{|l|}{ humans } \\
\hline hBD-1 & kidney, pancreas, female reproductive tract, airway, intestine & $11,12,13,47$ \\
\hline hBD-2 & skin, lung, trachea & 14,15 \\
\hline hBD-3 & skin, tonsil, placenta, testis, esophagus, trachea, heart, skeletal muscle, neutrophil & $16,17,18$ \\
\hline hBD-4 & epididymis, gastric antrum, lung & $26,27,67,68$ \\
\hline hBD-5 & epididymis & 26,66 \\
\hline hBD-6 & epididymis & 26,66 \\
\hline SPAG11 variant D & epididymis, airway & 17,26 \\
\hline DEFB118 & epididymis & 70 \\
\hline DEFB125 & epididymis & 71 \\
\hline DEFB126 & epididymis, pancreas & 71 \\
\hline DEFB127 & epididymis & 71 \\
\hline DEFB128 & epididymis & 71 \\
\hline DEFB129 & epididymis & 71 \\
\hline \multicolumn{3}{|l|}{ Mice } \\
\hline mBD-1 & kidney, tongue, female reproductive tract, proximal airway, esophagus & 19,20 \\
\hline $\mathrm{mBD}-2$ & kidney, uterus, trachea & 21 \\
\hline $\mathrm{mBD}-3$ & tongue, esophagus, salivary gland, epididymis, pancreas, proximal airway & 22,25 \\
\hline $\mathrm{mBD}-4$ & tongue, esophagus, trachea & 23,25 \\
\hline $\mathrm{mBD}-6$ & tongue, esophagus, skeletal muscle & 25 \\
\hline mBD-14 & skin, tonsil, toungue, urinary bladder, thymus & 28 \\
\hline $\mathrm{mBD}-12$ & epididymis & 26 \\
\hline mBD-15 & epididymis & 26 \\
\hline SPAG11variant E & epididymis & 26 \\
\hline
\end{tabular}

have a specific six-cysteine motif, which allows nucleotide sequence analysis to be performed for the identification of candidate defensin genes.

We also hypothesized that unidentified $\beta$-defensin genes may still exist in this gene cluster, and first identified mBD- 6 by using degenerative polymerase chain reaction (PCR) on a bacterial artificial chromosome clone containing the $\mathrm{mBD}-3$ gene. ${ }^{25)}$ The existence of a corresponding transcript was confirmed by reverse transcription (RT)-PCR on mouse skeletal muscle cDNA (Fig. 1). The sixcysteine motif characteristic to the $\beta$-defensin family is completely conserved in this novel peptide. Similar to other $\beta$-defensins, mBD- 6 has a sequence matching a signal peptide, which suggests that $\mathrm{mBD}-6$ is also a secretory peptide.

2-2. Tissue distribution of $\mathrm{mBD}-3, \mathrm{mBD}-4$, mBD-6, and mBD-14. mBD-3, mBD-4, and mBD6 are predominantly expressed in the tongue and esophagus, while their expression in the heart, brain, spleen, lung, liver, and kidney are much lower (Table 1). ${ }^{23), 25)}$ The expression of mBD-14, the mouse homologue of $\mathrm{hBD}-3$, was reported in the tongue, skin, urinary bladder, tonsil, and thymus. ${ }^{28)}$ The predominant expressions in these tissues suggest that $\mathrm{mBD}-3, \mathrm{mBD}-4, \mathrm{mBD}-6$, and $\mathrm{mBD}-14$ isoforms contribute to the host defense in the mucosal and epidermal surfaces exposed to the external environment.

Although the expression pattern of mBD-6 was similar to that of $\mathrm{mBD}-3$ and $\mathrm{mBD}-4, \mathrm{mBD}-6$ showed relatively high expression in skeletal muscle (Table 1). ${ }^{25)}$ RT-PCR analysis had also revealed hBD-3 expression in the skeletal muscle although the signal intensity was not as high as that in the placental membrane. ${ }^{17}$ ) The specific significance of $\beta$-defensin expression in the skeletal muscle remains to be determined.

\section{Computational whole-genome search for putative $\beta$-defensin genes}

3-1. Novel $\beta$-defensin gene clusters in human and mouse genome. After determination of consensus sequences of the human and mouse 


\section{A. human and mouse $\beta$-defensin gene cluster on chromosome 8}

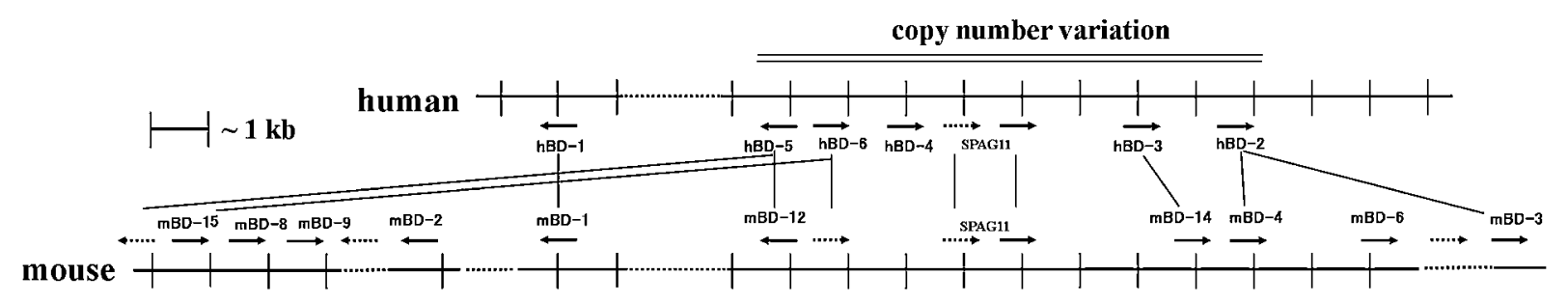

\section{B. Splicing variant of SPAG 11}

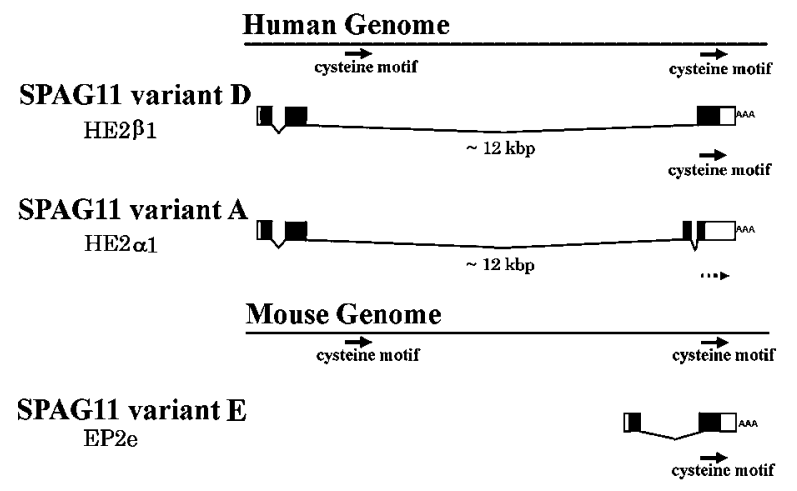

Fig. 2. $\quad \beta$-defensin gene cluster in chromosome 8 of humans and mice. A. The arrow indicates the presence of nucleotide sequence that can encode the $\beta$-defensin-specific cysteine motif. The expression of the $\beta$-defensin isoforms shown by solid arrows has been confirmed. The lines connecting the human and mouse genes indicate the homologies. The region indicated by doublet shows copy number variations in human genome. B. Schematic view of the splicing variants in SPAG11. Spag11 variant D and E contain the six-cysteine motif characteristic of $\beta$-defensins. While the genomic sequences of the SPAG11 region are conserved between humans and mice, the expression patterns of splice variants from this region differ.

genomes, a computational whole-genome search was performed for possible $\beta$-defensin genes. $^{29)}$ This search discovered five $\beta$-defensin gene clusters in the human and mouse genomes in addition to the known defensin gene cluster on chromosome 8 . Surprisingly, 33 human genes and 44 mouse genes can encode the amino acid sequence containing the $\beta$-defensin-specific six-cytsteine motif. However, the expression or functions of many possible $\beta$-defensin genes have not been sufficiently evaluated.

3-2. Nomenclature for $\boldsymbol{\beta}$-defensin genes. In response to the identification of many putative $\beta$ defensin genes, the HUGO Gene Nomenclature Committee and the Mouse Genomic Nomenclature Committee made the consensus for names of $\beta$ defensin genes in humans and mice. In brief, the human $\beta$-defensin gene names are termed DEFB, and the isoform number begins with the numeral 101. For example, the gene name for hBD-5 is DEFB105. The mouse $\beta$-defensin gene names are termed defb, and the isoform number begins with the numeral 1 . For example, the gene name for mBD-12 is defb12.

\section{The genomic features of defensins}

4-1. Copy number variation in defensin gene cluster. Interestingly, some regions of the human genome are duplicated one or more times. While single nucleotide polymorphisms have been investigated intensively, the clinical significance of these copy number variations $(\mathrm{CNVs})$ remains to be well evaluated. However, the constructed human CNV map shows that CNV regions encompass nearly $12 \%$ of the human genome. ${ }^{30)}$

During the past four years, genome-wide studies have revealed that defensin region of human chromosome 8 is one of the representative loci showing CNV. ${ }^{31)}$ There are multiple copies of the genomic regions spanning hBD-2, -3, -4, -5, -6, and Spermassociated antigen 11 (SAPG11) genes (Fig. 2), and multiple copies of the genomic regions spanning HNP-1/3. Individual copy numbers of these regions vary from 1 copy to more than 10 copies.

Furthermore, HNP-1 and HNP-3 share almost the same amino acid sequences, and some families 


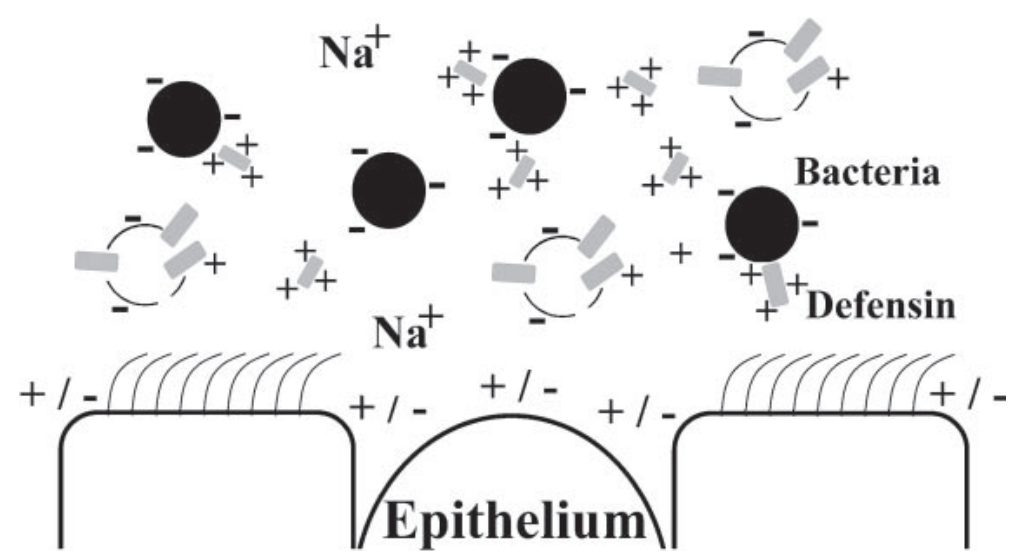

Fig. 3. A schematic representation of the host defense by $\beta$-defensin. The cationic antimicrobial peptides selectively bind to bacterial membranes because the bacterial membranes are negatively charged. The outer leaflets of the plasma membranes of mammalian cells are neutral in charge. Once bound to bacterial membranes, the antimicrobial peptides generate pores in the membrane.

have been found to lack a functional HNP-3 gene. ${ }^{31)}$ In mice, enteric $\alpha$-defensin genes, named cryptdin, are quite variable among strains at the genome level, ${ }^{31), 32)}$ and the nomenclature for these genes is confusing. ${ }^{33)}$ Some cryptdin genes are apparently duplicated without any altered amino acid residues in mature peptides. This genomic variability may be a consequence of defensin gene duplication and subsequent selection during evolution.

4-2. Defensin genes are not well conserved between species. Defensin genes are not well conserved between species. This may be a consequence of evolutionary selection on duplicated defensin genes. Figure 2A shows the absence of any human homologues of mBD-2 or mBD-6, and the absence of a mouse homologue of hBD-4. Although both mBD-3 and mBD-4 are considered mouse homologues of hBD-2, only $40 \%$ of amino acid residues in $\mathrm{mBD}-3$ or $\mathrm{mBD}-4$ are identical with those of hBD-2 (Fig. 2B).

Furthermore, $\alpha$-defensin has not been detected in mouse neutrophils, ${ }^{32)}$ while human $\alpha$-defensin is a major component of azurophil granules of human neutrophils. While human intestine expresses two $\alpha$-defensin isoforms, HD-5 and HD-6, mouse intestine expresses nearly twenty $\alpha$-defensin isoforms (cryptdin). The identification of mouse homologues of human enteric defensins is difficult.

These variations should not be taken to mean a low importance for defensins in maintaining life. Evolutionary selection might have promoted the divergences of amino acid sequences of defensins because of critical roles in maintaining host defense against strain-specific pathogens. Furthermore, most defensin isoforms conserve structural and chemical features, even though the amino acid sequences are not well conserved.

\section{The antimicrobial features of defensin}

5-1. General character of the antimicrobial activities of defensins. Most antimicrobial peptides possess two conserved chemical features, a positive charge with basic amino acid residues, and amphiphilicity, with both hydrophilic amino acid residues and hydrophobic amino acid residues.

The positive charge of antimicrobial peptides is one of the most important factors contributing to selectivity against bacteria. Mellitin, a major component of bee venom, is electrically neutral, and shows potent cytotoxicity against mammalian cells in addition to antimicrobial activity. Because bacterial membranes are negatively charged, the cationic antimicrobial peptides selectively bind to bacterial membranes, while the outer leaflets of the plasma membranes of mammalian cells are neutral in charge. $^{34)}$ Once bound to bacterial membranes, antimicrobial peptides generate pores in the membrane and the increased permeability causes the death of the bacteria (Fig. 3).

Defensins are also cationic, amphiphilic peptides. The antimicrobial activity of defensins is salt-dependent. High concentrations of $\mathrm{NaCl}$ diminish the antimicrobial activities of most isoforms of defensin. We also evaluated the antimicrobial activities of synthetic mBD-6 peptide. The synthesized peptide showed potent bactericidal activity against Escherichia coli at a concentration of $20 \mu \mathrm{g} / \mathrm{ml} .^{25)}$ This potency was almost equal to other $\beta$-defensins. 
The antimicrobial potency of mBD-6 was significantly reduced at high concentrations of $\mathrm{NaCl}$, similar to that reported on hBD-1, hBD-2, and mBD-1. 11),14),15),20)

However, recent reports have shown that hBD-3 and HNP exert its antimicrobial activity by inhibiting the synthesis of the bacterial cell wall, which is completely different mechanism from the known mechanisms of other antimicrobial peptides. ${ }^{35), 36)}$ The mode of antibiotic action of defensins is not simple. ${ }^{37)}$

5-2. Isoform-specific features of the antimicrobial activities of defensins. In contrast with the reported antimicrobial features of many defensin isoforms, hBD-3 preserved its antimicrobial activity independent of the environmental sodium concentration. ${ }^{16)}$ hBD-3 also showed potent antimicrobial activities against gram-positive bacteria. ${ }^{16)}$

In addition, a recent study indicated that hBD-1 shows potent antimicrobial activity against Candida and anaerobic gram-positive bacteria after its three disulphide bonds are cleaved under reducing conditions such as those in the intestinal tract. ${ }^{38)}$

These isoform-specific features of antimicrobial activities may explain why it might be beneficial to express multiple isoforms in one tissue. Each defensin isoform may play a specific role dependent on a variable microenvironment and the strain of targeted microbes.

\section{Regulation of $\beta$-defensin expression}

6-1. Regulation of hBD-2 expression. The discovery that hBD-2 expression is induced by LPS attracted the interest of many investigators studying antimicrobial peptides. ${ }^{14)}$ We also observed that LPS elevated hBD-2 mRNA levels in LC-2/ad cells, a human airway cell line, in a time- and dose-dependent manner, while hBD-2 mRNA was not detectable at baseline. ${ }^{39)}$ The LPS-induced elevation of hBD-2 mRNA was partially inhibited by pyrrolidine dithiocarbamate pretreatment, which supported a contribution of the $\mathrm{NF}-\kappa \mathrm{B}$ pathway to the regulation of hBD-2 expression.

In addition to LPS, hBD-2 expression is induced by various pro-inflammatory agents such as TNF- $\alpha$, IL-1 $\beta$, and IL- $8 .{ }^{40), 41)}$ These findings indicate that defensins represent one component of inflammatory responses similar to those of various cytokines and oxidants.

The 5'-flanking region of hBD-2 contains consensus binding sequences for $\mathrm{NF}-\kappa \mathrm{B}$ and $\mathrm{AP}-1$. Investigation using luciferase analysis in the intesti- nal epithelial cells revealed that hBD-2 promoter constructs with mutated NF- $\kappa \mathrm{B}$ or AP-1 sites did not respond to stimulation with E. coli. ${ }^{42)}$ Evaluation of hBD-2 expression induced by Legionella pneumophila infection has also helped to illuminate the pathways regulating hBD-2 expression. ${ }^{43}$ The p38 and JNK inhibitors were found to inhibit the induction of hBD-2 expression after infection with Legionella, while an ERK inhibitor did not inhibit the induction of hBD-2 expression. JNK activated c-Jun, a component of the AP-1 transcription factor complex, after infection with Legionella.

6-2. Regulation of hBD-3 expression. Schröder et al. first isolated hBD-3 from the human skin and also indicated that hBD-3 expression was induced by Pseudomonas aeruginosa. ${ }^{16)}$ A peculiar feature of hBD-3 regulation is its induction by interferon- $\gamma{ }^{18)}$ Consistent with the known primary pathway of interferon- $\gamma$, STAT1 decoy oligodeoxynucleotide or STAT1 siRNA inhibited the hBD-3 induction by interferon- $\gamma \cdot{ }^{44)}$

\section{Novel roles of defensin as a regulator of immune response}

The report of Oppenheim et al. was epochmaking in the area of defensin investigation. ${ }^{45)}$ They showed that $1 \mu \mathrm{g} / \mathrm{ml}$ of hBD-2 contributes to the chemoattraction of immature dendritic cells through the CCR6 receptor. They first identified a receptor directly activated by defensins, and proposed a novel role of defensins linking innate immunity and acquired immunity.

Other novel findings about the function of defensins through specific mammalian receptors are reported. mBD-2 has the capacity to promote the maturation of immature dendritic cells through Toll-like receptor $4 .^{46)}$ hBD-3 induces the expression of CD80, CD86, and CD40 on myeloid dendritic cells through Toll-like receptors 1 and $\left.2 .^{47}\right)$

hBD-1, hBD-2, hBD-3, and hBD-4 all showed a chemoattractive function on macrophages. ${ }^{48)}$ Because macrophages have no CCR6 receptors, the identification of other receptors for $\beta$-defensins had been pursued. A recent report revealed that hBD-2 and hBD-3 interact with CCR2 on monocytes, macrophages, and neutrophils, leading to the chemotaxis of these cells. ${ }^{49)}$

Defensins also induce the expression of various cytokines. Neutrophil defensins have been found to augment the expression of IL- 8 in the airway epithelial cells through the P2Y6 receptor. ${ }^{50)}$ Niyonsaba et al. showed that hBD-1, -2, -3, and -4, 
and LL-37 induced the expression of IL-18 through the activation of p38 and ERK. ${ }^{51)}$ LL-37 is an antimicrobial peptide of the cathelicidin family. The evaluation of cytokine secretion from peripheral mononuclear cells using protein array analysis showed an increased release of various cytokines following stimulation with hBD-1, hBD-2, or hBD-3. ${ }^{52)}$

Defensin secretion represents the frontline of host defense, and the expression of hBD-2 and hBD-3 are regulated by the bacterial invasion. The hypothesis of the linkage between innate immunity and acquired immunity by defensin is very attractive. However, the functions of defensins in regulating the adaptive immune system have not been evaluated in vivo. All of the reported receptors of antimicrobial peptides have other intrinsic ligands, and it is not yet clear how defensins modulate these pathways in vivo.

\section{The contribution of antimicrobial peptides to host defense in vivo}

8-1. Antimicrobial activities in nasal discharges. Eighty years ago, Fleming, who is famous for the discovery of penicillin, reported the antimicrobial activity of nasal discharge. ${ }^{53}$ This was the first report that showed an intrinsic chemical protection from microorganisms in the airway.

The report of Ganz et al. showed that 12.5\% of the subjects showed Staphylococcus aureus (S. aureus) colonization. ${ }^{54)}$ Interestingly, S. aureus grew in the nasal discharge of subjects with $S$. aureus colonization, and did not grow in the nasal discharge of subjects without $S$. aureus colonization. These findings imply that differences in the components of nasal discharges determine individual susceptibility to $S$. aureus colonization. In addition, Ganz et al. suggested that the key component would be a small peptide, because heating nasal discharges did not diminish their antimicrobial activities. ${ }^{54)}$

8-2. Findings from the transgenic mice deficient in antimicrobial peptides. The immune contribution of antimicrobial peptides was clearly showed in vivo by the generation of CRAMPdeficient mice. ${ }^{55)}$ CRAMP is a murine antimicrobial peptide of the cathelicidin family. CRAMP deletion rendered mice more susceptible to severe Group-A streptococcal infection.

Characterization of matrilysin-deficient mice showed the significance of intestinal $\alpha$-defensin in vivo. ${ }^{56)}$ Mouse intestinal $\alpha$-defensin is secreted as an inactive form and activated through cleavage of the precursor by matrilysin. Matrilysin-deficient mice, which are unable to activate intestinal $\alpha$ defensins, are significantly susceptible to Salmonella typhimurium (S. typhimurium) lethal infection. Furthermore, transgenic mice having human genomic sequences of HD-5 showed an increased resistance to a lethal dose of $S$. typhimurium infection. ${ }^{57}$ )

The immune contribution of $\beta$-defensin was evaluated in vivo using $\mathrm{mBD}-1$-deficient mice, which showed a significantly prolonged infection of Haemophilus influenzae in the lungs. ${ }^{58)}$ Although the phenotype of mBD-1-deficient mice was less dramatic than that of matrilysin knockout mice, this is reasonable considering that various defensin isoforms are expressed in airway, and these isoforms may partially functionally compensate for mBD-1 deficiency.

8-3. Normal flora and defensins. Certainly, defensins and other antimicrobial peptides are important in preventing lethal infections of some specific microorganisms. However, tissues like the skin, urethra and oral cavity, where many isoforms of defensin are expressed, show extensive bacterial colonization without pathogenesis. Defensins in these tissues may function not to eradicate bacteria, but to control the normal flora by interacting with the colonizing bacteria.

Another report on mBD-1-deficient mice showed an increased bacterial colonization in the urethra. ${ }^{59}$ Of particular interest, evaluation of matrilysindeficient mice (which lack $\alpha$-defensin activation), HD-5-expressing mice, and wild-type mice showed compositional changes in colonizing bacterial communities, while the total number of bacteria did not significantly differ between these mouse genotypes. ${ }^{60)}$

\section{Defensins in the epididymis}

9-1. Identification of human $\beta$-defensin-5, human $\beta$-defensin-6, and their mouse homologues. On the basis of the publicly available human genome sequence, we identified multiple sequences that may encode $\beta$-defensin peptides having the characteristic six-cysteine motif (Fig. 2). The expression of two corresponding transcripts of these putative genes were confirmed by RT-PCR using RNA from the human epididymis. ${ }^{26)}$ These novel peptides were named hBD-5 and hBD-6 (Fig. 1).

We also identified the mouse homologues of hBD-5 and hBD-6, which were present in the mouse epididymis. This mouse hBD-5 homologue was named mBD-12. Although the mouse hBD-6 homologue was initially named $\mathrm{mBD}-11$, this peptide is 


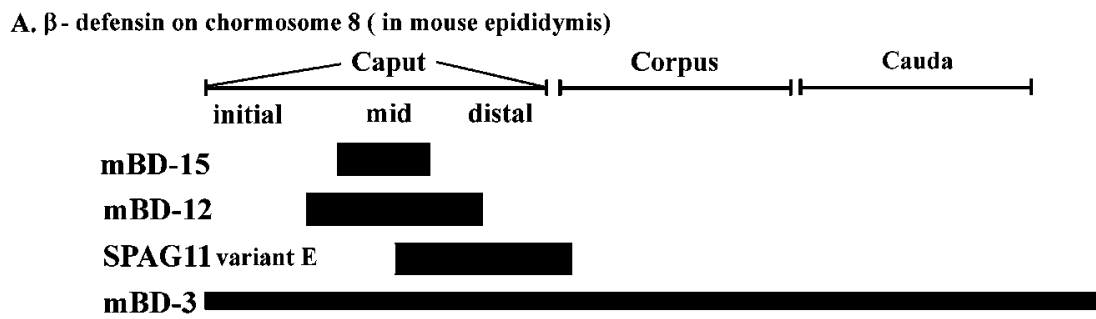

B. $\beta$ - defensin on chormosome 20 ( in human epididymis)

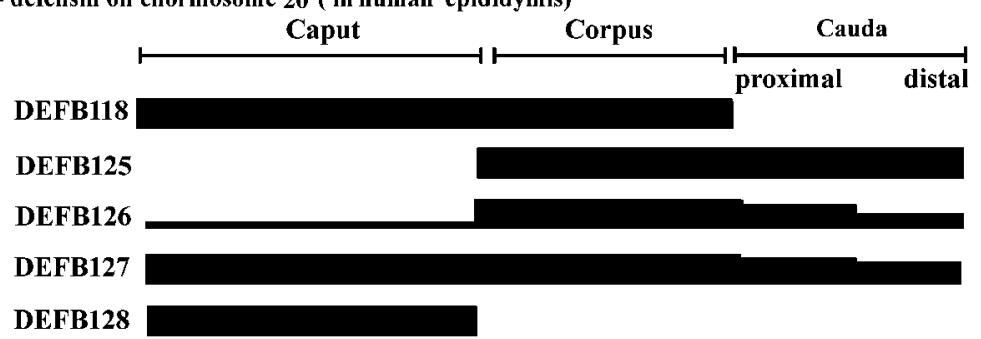

Fig. 4. Local distribution of $\beta$-defensin in the epididymis. A. The bar indicates the region where each $\beta$-defensin isoform is expressed. mBD-15, mBD-12, and SPAG11 variant E show region-specific expression in the mouse epididymis, while mBD-3 shows ubiquitous expression in the caput, corpus, and caudal region. B. The local distribution of human $\beta$-defensin isoforms on chromosome 20 . DEFB 125, 126, 127, and 129 expression are most abundant in the corpus.

currently called mBD-15. The synthetic mBD-12 peptide showed potent antimicrobial activities against Escherichia coli at a concentration of $20 \mu \mathrm{g} / \mathrm{ml}$.

9-2. Sperm-associated antigen 11 protein. Sperm-associated antigen 11 (SAPG11) had been originally named HE2 or EP2 protein. HE2 protein was first identified from human epididymis cDNA libraries as a novel transcript specifically expressed in the human epididymis. ${ }^{61), 62)}$ The HE2 gene encodes multiple splice variants, and HE2 $\beta 1$, EP2c, and EP2e contain the six-cysteine motif characteristic of $\beta$ defensins $^{63)}$ (Fig. 2B). HE2 $\beta 1$ currently corresponds to SPAG11 variant D.

Bin1b was identified as a novel $\beta$-defensin in the rat epididymis. ${ }^{64)}$ Bin1b shows region-specific expression in the epididymis and has antimicrobial activities. Amino acid sequence analysis showed that Bin1b corresponds to SPAG11 variant $\mathrm{E}$.

The degenerate PCR amplification of mouse epididymis cDNA using primers common to HE2 $\beta 1$ and Bin1b revealed a novel $\beta$-defensin sequence homologous with Bin1b. This transcript corresponds to mouse SAPG11 variant E. The amplification of the predicted SPAG11 variant C transcript by RTPCR has been also reported in the rat and mouse epididymis. ${ }^{65)}$ A mouse splicing variant corresponding to human SPAG11 variant $D$ has not been detected (Fig. 2B).
9-3. $\beta$-defensin isoforms expressed predominantly in the epididymis. Interestingly, Bin1b was not expressed in any other major organs, such as the lung or kidney, except the epididymis. ${ }^{64)}$ RTPCR examination showed that hBD-4, hBD-5, hBD6 , and SPAG11 variant D were expressed predominantly in the human epididymis (Table 1). ${ }^{26), 66)}$ Although these $\beta$-defensin genes are also expressed in other organs, e.g. hBD-4 in the gastric antrum, lungs, and in cultured keratinocytes, ${ }^{27), 67)-69)}$ and SPAG11 variant D is expressed in cultured oral and pulmonary epithelial cells, ${ }^{17)}$ the expression of hBD-4 and SPAG11 variant D are much higher in the epididymis than in other organs under normal physiological conditions.

Similarly, RT-PCR for mBD-15, mBD-12, and mouse SPAG 11 variant E showed a higher RNA expression of these genes in the epididymis than in other tissues. The tissue specificities of these isoforms were clearly different from those of $\mathrm{mBD}-3, \mathrm{mBD}-4$, mBD-6 and mBD-14.

9-4. Region-specific defensin expression in the epididymis. The region specificity is a peculiar feature of the mBD-15, mBD-12, mouse SPAG 11 variant $\mathrm{E}$, and rat $\mathrm{Bin} 1 \mathrm{~b}$ expression within the epididymis (Fig. 4). ${ }^{26), 64)} \mathrm{mBD}-15$ and mBD-12 expression was most prominent in the epididymis caput region and was completely absent in the seminal tract, seminal vesicle, and bladder. SPAG11 variant 
E expression was also most prominent in the caput region, but a comparable level of expression was detected in the corpus region. In contrast, mBD-3 showed ubiquitous expression in the caput, corpus, and caudal region, and even in the seminal tract.

After the discovery of five $\beta$-defensin gene clusters in the human and mouse genomes, the tissue distributions of DEFB118, 125, 126, 127, 128, and 129 genes, which are encoded on chromosome 20, were reported. These genes are also expressed predominantly in the human epididymis. ${ }^{70), 71)}$ Their expression was found to be most abundant in the caput or corpus regions of the epididymis with slight variations between isoforms (Fig. 4).70),71)

9-5. The features of the epididymis-predominant $\boldsymbol{\beta}$-defensin isoforms. $\beta$-defensin isoforms can be grouped into two groups: epididymis-predominant isoforms and non-epididymis-predominant isoforms. In humans, the former group includes SPAG11 variant $\mathrm{D}$, hBD-4, hBD-5, and hBD-6, and the latter group includes hBD-1, hBD-2, and hBD-3. Although epididymis-predominant $\beta$-defensin genes are also expressed in other organs, the pattern of tissue distribution is completely different between the two groups. Interestingly, all of the human epididymispredominant $\beta$-defensin genes are located within a region encompassing $40 \mathrm{~kb}$ on chromosome 8 (Fig. 2). In mice, mBD-15, mBD-12, and SPAG11 variant $\mathrm{E}$ are predominantly expressed in the epididymis. Although DEFB126 is expressed in the pancreas and male reproductive organs equally, ${ }^{71)}$ the tissue distribution of DEFB118, 125, 126, 127, 128, and 129 on chromosome 20 is near the group of epididymispredominant $\beta$-defensin genes.

Some amino acid residues are differentially conserved between the two groups (Fig. 1). The glutamic acid residue four positions after the C3 residue is conserved in the epididymis-predominant $\beta$-defensin isoforms, while the glycine residue three positions before the $\mathrm{C} 2$ residue is conserved in the non-epididymis-predominant group. Whether these differences are biologically significant, or whether they only reflect evolutionary relations between defensin genes remains to be clarified.

Because the epididymis is anatomically contiguous with the urethra, the epididymis is always at a risk of ascending microbial invasion. Acute epididymitis is a common sexually transmitted disease caused by bacterial infections of the epididymis. Therefore, strong host defense against bacterial pathogens in the epididymis has a high evolutionary importance for the protection of the spermatozoa.
9-6. A novel function of defensin in the epididymis. In addition to their predicted importance for host defense in the epididymis, their region-specific expression patterns suggested the existence of epididymis-specific roles in these peptides. Immunostaining for SPAG11 family proteins indicated the binding of SPAG11 to the sperm head, suggesting a possible role in sperm maturation. ${ }^{61)}$ Furthermore, Zhou et al. showed that Bin1b binds to the sperm and is essential for the induction of progressive sperm motility. The suppression of Bin1b expression results in a considerable attenuation of sperm motility. ${ }^{72)}$ Likewise, immunization with Bin1b peptide induced the production of antiBin1b antibodies and resulted in reduced fertility in rats. ${ }^{73)}$

DEFB126 is encoded in the defensin gene cluster on human chromosome 20 . While hBD-1, -2 , and -3 are not modified after synthesis of the mature peptides, DEFB126 is a highly sialylated glycopeptide. A macaque homologue of DEFB126 coats the entire surface of macaque sperm, similar to human SPAG11 family proteins and Bin1b. Coating of sperm by DEFB126 is required for the binding of sperm to oviductal epithelial cells, and the subsequent DEFB126 uncoating is required for the capacitation of sperm. ${ }^{74}$ In addition, blocking DEFB126 using anti-DEFB126 antibodies inhibited the cervical mucus penetration of sperm in vitro. ${ }^{75)}$

Interestingly, recent investigations of frequent mutations in human DEFB126 genes have shown that homozygous variants of the DEFB126 gene exhibit reduced sperm penetration ability and are associated with reduced fertility. These findings indicate a critical role of human DEFB126 in malefactor infertility. ${ }^{76)}$

\section{Defensins in inflammation}

10-1. Increased defensin concentrations in inflammatory lung diseases. Importantly, the concentrations of $\alpha$-defensin in the bronchoalveolar lavage fluid (BALF) of acute respiratory distress syndrome (ARDS) patients are 50 times higher than those of healthy patients. ${ }^{77)}$ Likewise, a proteomic analysis revealed that neutrophil defensins showed a remarkable increase in concentration in the BALF of chronic obstructive pulmonary diseases (COPD) patients compared to asymptomatic smokers. ${ }^{78)}$ The analysis of global gene expression in acute exacerbations of idiopathic pulmonary fibrosis revealed that $\alpha$-defensins are one of the most up-regulated genes between the stable and acute-exacerbated states. ${ }^{79)}$ 


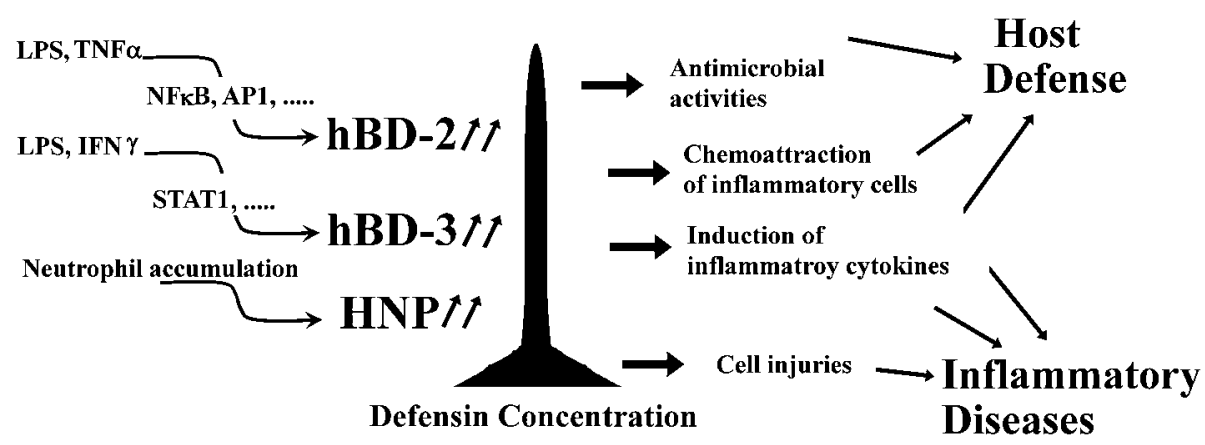

Fig. 5. The role of defensins as a component of the inflammatory response. The expression of human $\beta$-defensin-2 (hBD-2) and human $\beta$ defensin-3 (hBD-3) expression can be augmented by stimulation with lipopolysaccharide (LPS) and various other cytokines. Human neutrophil peptide (HNP) is contained abundantly in neutrophil granules. At the same time, defensins have the capacity to chemoattract immune cells and to induce inflammatory cytokines. At high concentrations, defensins can even be cytotoxic to mammalian cells. The oversecretion of defensin may contribute to the pathogenesis of various inflammatory diseases.

Neutrophil accumulation would be accompanied by the increase of neutrophil defensin concentration (Fig. 5). However, these findings can not indicate whether the increased defensin concentration contributes to the worsening of these inflammatory diseases, or whether this only reflects the exaggerated state of inflammation.

10-2. Transgenic mice overexpressing $\beta$ defensin. Human neutrophil $\alpha$-defensin causes cell lysis in various cultured cells through the permeabilization of the cell membrane ${ }^{80)}$ and subsequent DNA injury. ${ }^{81)}$ Similarly, treatment of mouse blastocysts with hBD-2 causes degeneration and death of blastocysts. ${ }^{82}$ )

To investigate the pathogenic significance of increased defensin secretion in an animal model, we generated transgenic mice overexpressing mBD-6 under the control of the chicken $\beta$-actin promoter. ${ }^{83)}$ The transgene was transmitted to the germline in two lines, referred to as Tg1 and Tg2. Tg1 mice showed higher expression of the transgene than Tg2 mice. Few Tg1 mice lived for more than 1 year. We could not clarify the specific causes of death for $\mathrm{Tg} 1$ mice, although one characteristic feature was a severe loss of body weight and severe kyphosis, indicating functional impairment of skeletal muscle. Hematoxylin and eosin staining of skeletal muscle revealed centronucleated myofibers and faintly stained necrotic myofibers in the 8 -week-old Tg1 mice and the 1-year-old Tg2 mice.

The recent report of Cines et al. supported the pathogenic significance of defensin oversecretion in inflammatory lung diseases. ${ }^{84)}$ Cines et al. generated transgenic mice having the genomic sequences of human neutrophil defensin. These transgenic mice expressed human defensin in neutrophils, and showed more prominent vascular permeability following the intratracheal instillation of $\mathrm{HCl}$ compared to wildtype mice, indicating that neutrophil defensin would worsen ARDS caused by the aspiration of acidic contents.

While the immune response is indispensable for human survival, an excessive inflammatory response is harmful and leads to various disorders. In addition to their potent antimicrobial effects, defensins may act on diverse immune cells and epithelial cells to regulate the whole immune response. Furthermore, defensins exert cytotoxic effects on mammalian cells. The studies of these transgenic mice have shown that defensins could potentially contribute to pathogenic processes, although more physiological models would be required to establish the pathogenic significance of defensin oversecretion.

\section{Recent investigations on the copy number variations of defensin genes}

Recent investigations on the genomic CNV of defensin genes revealed an interesting association between the expression of defensins and inflammatory diseases. The copy number of neutrophil $\alpha$ defensin genes in patients with severe sepsis was significantly higher than that in healthy controls. ${ }^{85)}$

Comparison of the $\beta$-defensin copy number between COPD patients and healthy smokers indicated that the presence of 5 or more $\beta$-defensin copies was associated with an increased incidence of COPD. ${ }^{86)}$

Furthermore, a high incidence of psoriasis was significantly associated with higher copy number of $\beta$-defensin genes. $\left.{ }^{87}\right)$ 


\section{Perspective}

While immune responses are indispensable for the survival of humans, dysregulation of the inflammatory response is harmful and can lead to various disorders. Because the expression of hBD-2 and hBD3 is regulated by various cytokines, overstimulation of hBD- 2 or hBD-3 secretion could augment pathogenic processes in inflammation. Recent investigations on the CNVs of defensin genes strongly suggest a contribution of defensins to the pathogenesis of inflammatory diseases.

Although the molecular mechanisms of inflammatory diseases like ARDS and COPD have been intensively investigated, fundamental therapies to reduce inflammation in these diseases remain to be established. Because cytokines function within a complex network of interactions, it is difficult to identify the molecules that are likely to be key targets for treatment. Because defensins have multiple effects on mammalian cells, they may be a unique target for novel strategies to treat inflammatory diseases.

\section{Acknowledgements}

The author thanks all the collaborators concerned with the studies described in this review article, who are listed as the co-authors of the paper. This work was supported by Grants-in-Aid for Scientific Research from the Ministry of Education, Culture, Sports, Science and Technology of Japan, Grants-in-Aid for Comprehensive Research on Aging and Health from the Ministry of Health, Labor and Welfare of Japan, and a Research Grant from Uehara Memorial Foundation.

\section{References}

1) Hoffmann, J.A., Kafatos, F.C., Janeway, C.A. and Ezekowitz, R.A. (1999) Phylogenetic perspectives in innate immunity. Science 284, 1313-1318.

2) Strominger, J.L. (2009) Animal antimicrobial peptides: ancient players in innate immunity. J. Immunol. 182, 6633-6634.

3) Steiner, H., Hultmark, D., Engström, Å., Bennich, H. and Boman, H.G. (1981) Sequence and specificity of two antibacterial proteins involved in insect immunity. Nature 292, 246-248.

4) Zasloff, M. (1987) Magainins, a class of antimicrobial peptides from Xenopus skin: isolation, characterization of two active forms, and partial cDNA sequence of a precursor. Proc. Natl. Acad. Sci. U.S.A. 84, 5449-5453.

5) Ganz, T., Selsted, M.E., Szklarek, D., Harwig, S.S., Daher, K., Bainton, D.F. and Lehrer, R.I. (1985) Defensins. Natural peptide antibiotics of human neutrophils. J. Clin. Invest. 76, 1427-1435.

6) Diamond, G., Zasloff, M., Eck, H., Brasseur, M., Maloy, W.L. and Bevins, C.L. (1991) Tracheal antimicrobial peptide, a cysteine-rich peptide from mammalian tracheal mucosa: peptide isolation and cloning of a cDNA. Proc. Natl. Acad. Sci. U.S.A. 88, 3952-3956.

7) Selsted, M.E., Tang, Y.Q., Morris, W.L., McGuire, P.A., Novotny, M.J., Smith, W., Henschen, A.H. and Cullor, J.S. (1993) Purification, primary structures, and antibacterial activities of $\beta$-defensins, a new family of antimicrobial peptides from bovine neutrophils. J. Biol. Chem. 268, 66416648

8) Tang, Y.Q., Yuan, J., Ösapay, G., Ösapay, K., Tran, D., Miller, C.J., Ouellette, A.J. and Selsted, M.E. (1999) A cyclic antimicrobial peptide produced in primate leukocytes by the ligation of two truncated $\alpha$-defensins. Science 286, 498-502.

9) Hazlett, L. and Wu, M. (2011) Defensins in innate immunity. Cell Tissue Res. 343, 175-188.

10) Bensch, K.W., Raida, M., Mägert, H.J., SchulzKnappe, P. and Forssmann, W.G. (1995) hBD-1: a novel $\beta$-defensin from human plasma. FEBS Lett. 368, 331-335.

11) Valore, E.V., Park, C.H., Quayle, A.J., Wiles, K.R., McCray, P.B. Jr. and Ganz, T. (1998) Human $\beta$ defensin-1: an antimicrobial peptide of urogenital tissues. J. Clin. Invest. 101, 1633-1642.

12) Zhao, C., Wang, I. and Lehrer, R.I. (1996) Widespread expression of $\beta$-defensin hBD-1 in human secretory glands and epithelial cells. FEBS Lett. 396, 319-322.

13) Fulton, C., Anderson, G.M., Zasloff, M., Bull, R. and Quinn, A.G. (1997) Expression of natural peptide antibiotics in human skin. Lancet 350, 1750-1751.

14) Harder, J., Bartels, J., Christophers, E. and Schröder, J.M. (1997) A peptide antibiotic from human skin. Nature 387, 861.

15) Bals, R., Wang, X., Wu, Z., Freeman, T., Bafna, V., Zasloff, M. and Wilson, J.M. (1998) Human $\beta$ defensin 2 is a salt-sensitive peptide antibiotic expressed in human lung. J. Clin. Invest. 102, $874-880$

16) Harder, J., Bartels, J., Christophers, E. and Schröder, J.M. (2001) Isolation and characterization of human $\beta$-defensin-3, a novel human inducible peptide antibiotic. J. Biol. Chem. 276, $5707-5713$.

17) Jia, H.P., Schutte, B.C., Schudy, A., Linzmeier, R., Guthmiller, J.M., Johnson, G.K., Tack, B.F., Mitros, J.P., Rosenthal, A., Ganz, T. and McCray, P.B. Jr. (2001) Discovery of new human $\beta$-defensins using a genomics-based approach. Gene 263, 211-221.

18) García, J.R., Jaumann, F., Schulz, S., Krause, A., Rodríguez-Jiménez, J., Forssmann, U., Adermann, K., Klüver, E., Vogelmeier, C., Becker, D., Hedrich, R., Forssmann, W.G. and Bals, R. (2001) Identification of a novel, multifunctional $\beta$-defensin (human $\beta$-defensin 3 ) with specific antimicrobial activity. Its interaction with plasma 
membranes of Xenopus oocytes and the induction of macrophage chemoattraction. Cell Tissue Res. 306, 257-264.

19) Huttner, K.M., Kozak, C.A. and Bevins, C.L. (1997) The mouse genome encodes a single homolog of the antimicrobial peptide human $\beta$-defensin 1 . FEBS Lett. 413, 45-49.

20) Bals, R., Goldman, M.J. and Wilson, J.M. (1998) Mouse $\beta$-defensin 1 is a salt-sensitive antimicrobial peptide present in epithelia of the lung and urogenital tract. Infect. Immun. 66, 1225-1232.

21) Morrison, G.M., Davidson, D.J. and Dorin, J.R. (1999) A novel mouse $\beta$ defensin, Defb2, which is upregulated in the airways by lipopolysaccharide. FEBS Lett. 442, 112-116.

22) Bals, R., Wang, X., Meegalla, R.L., Wattler, S., Weiner, D., Nehls, M.C. and Wilson, J.M. (1999) Mouse $\beta$-defensin 3 is an inducible antimicrobial peptide expressed in the epithelia of multiple organs. Infect. Immun. 67, 3542-3547.

23) Jia, H.P., Wowk, S.A., Schutte, B.C., Lee, S.K., Vivado, A., Tack, B.F., Bevins, C.L. and McCray, P.B. Jr. (2000) A novel murine $\beta$-defensin expressed in tongue, esophagus, and trachea. J. Biol. Chem. 275, 33314-33320.

24) Linzmeier, R., Ho, C.H., Hoang, B.V. and Ganz, T. (1999) A 450-kb contig of defensin genes on human chromosome 8p23. Gene 233, 205-211.

25) Yamaguchi, Y., Fukuhara, S., Nagase, T., Tomita, T., Hitomi, S., Kimura, S., Kurihara, H. and Ouchi, Y. (2001) A novel mouse $\beta$-defensin, mBD6 , predominantly expressed in skeletal muscle. J. Biol. Chem. 276, 31510-31514.

26) Yamaguchi, Y., Nagase, T., Makita, R., Fukuhara, S., Tomita, T., Tominaga, T., Kurihara, H. and Ouchi, Y. (2002) Identification of multiple novel epididymis-specific $\beta$-defensin isoforms in humans and mice. J. Immunol. 169, 2516-2523.

27) García, J.R., Krause, A., Schulz, S., RodríguezJiménez, F.J., Klüver, E., Adermann, K., Forssmann, U., Frimpong-Boateng, A., Bals, R. and Forssmann, W.G. (2001) Human $\beta$-defensin 4: a novel inducible peptide with a specific salt-sensitive spectrum of antimicrobial activity. FASEB J. 15, 1819-1821.

28) Hinrichsen, K., Podschun, R., Schubert, S., Schröder, J.M., Harder, J. and Proksch, E. (2008) Mouse beta-defensin-14, an antimicrobial ortholog of human beta-defensin-3. Antimicrob. Agents Chemother. 52, 1876-1879.

29) Schutte, B.C., Mitros, J.P., Bartlett, J.A., Walters, J.D., Jia, H.P., Welsh, M.J., Casavant, T.L. and McCray, P.B. Jr. (2002) Discovery of five conserved $\beta$-defensin gene clusters using a computational search strategy. Proc. Natl. Acad. Sci. U.S.A. 99, 2129-2133.

30) Redon, R., Ishikawa, S., Fitch, K.R., Feuk, L., Perry, G.H., Andrews, T.D., Fiegler, H., Shapero, M.H., Carson, A.R., Chen, W., Cho, E.K., Dallaire, S., Freeman, J.L., González, J.R., Gratacòs, M., Huang, J., Kalaitzopoulos, D., Komura, D., MacDonald, J.R., Marshall, C.R., Mei, R.,
Montgomery, L., Nishimura, K., Okamura, K., Shen, F., Somerville, M.J., Tchinda, J., Valsesia, A., Woodwark, C., Yang, F., Zhang, J., Zerjal, T., Zhang, J., Armengol, L., Conrad, D.F., Estivill, X., Tyler-Smith, C., Carter, N.P., Aburatani, H., Lee, C., Jones, K.W., Scherer, S.W. and Hurles, M.E. (2006) Global variation in copy number in the human genome. Nature 444, 444-454.

31) Hollox, E.J., Barber, J.C., Brookes, A.J. and Armour, J.A. (2008) Defensins and the dynamic genome: what we can learn from structural variation at human chromosome band 8p23.1. Genome Res. 18, 1686-1697.

32) Shanahan, M.T., Tanabe, H. and Ouellette, A.J. (2011) Strain-specific polymorphisms in Paneth cell $\alpha$-defensins of C57BL $/ 6$ mice and evidence of vestigial myeloid $\alpha$-defensin pseudogenes. Infect. Immun. 79, 459-473.

33) Amid, C., Rehaume, L.M., Brown, K.L., Gilbert, J.G., Dougan, G., Hancock, R.E. and Harrow, J.L. (2009) Manual annotation and analysis of the defensin gene cluster in the $\mathrm{C} 57 \mathrm{BL} / 6 \mathrm{~J}$ mouse reference genome. BMC Genomics 10, 606 .

34) Matsuzaki, K. (2001) Why and how are peptide-lipid interactions utilized for self defence? Biochem. Soc. Trans. 29, 598-601.

35) Sass, V., Schneider, T., Wilmes, M., Körner, C., Tossi, A., Novikova, N., Shamova, O. and Sahl, H.G. (2010) Human $\beta$-defensin 3 inhibits cell wall biosynthesis in Staphylococci. Infect. Immun. 78, 2793-2800.

36) de Leeuw, E., Li, C., Zeng, P., Li, C., Diepeveen-de Buin, M., Lu, W.Y., Breukink, E. and Lu, W. (2010) Functional interaction of human neutrophil peptide-1 with the cell wall precursor lipid II. FEBS Lett. 584, 1543-1548.

37) Wilmes, M., Cammue, B.P., Sahl, H.G. and Thevissen, K. (2011) Antibiotic activities of host defense peptides: more to it than lipid bilayer perturbation. Nat. Prod. Rep. 28, 1350-1358.

38) Schroeder, B.O., Wu, Z., Nuding, S., Groscurth, S., Marcinowski, M., Beisner, J., Buchner, J., Schaller, M., Stange, E.F. and Wehkamp, J. (2011) Reduction of disulphide bonds unmasks potent antimicrobial activity of human $\beta$-defensin 1 . Nature 469, 419-423.

39) Tomita, T., Nagase, T., Ohga, E., Yamaguchi, Y., Yoshizumi, M. and Ouchi, Y. (2002) Molecular mechanisms underlying human $\beta$-defensin-2 gene expression in a human airway cell line (LC2/ad). Respirology 7, 305-310.

40) Singh, P.K., Jia, H.P., Wiles, K., Hesselberth, J., Liu, L., Conway, B.A., Greenberg, E.P., Valore, E.V., Welsh, M.J., Ganz, T., Tack, B.F. and McCray, P.B. Jr. (1998) Production of $\beta$-defensins by human airway epithelia. Proc. Natl. Acad. Sci. U.S.A. 95, 14961-14966.

41) Harder, J., Meyer-Hoffert, U., Teran, L.M., Schwichtenberg, L., Bartels, J., Maune, S. and Schröder, J.M. (2000) Mucoid Pseudomonas aeruginosa, TNF $\alpha$, and IL- $1 \beta$, but not IL- 6 , induce human $\beta$-defensin- 2 in respiratory epithelia. Am. J. 
Respir. Cell Mol. Biol. 22, 714-721.

42) Wehkamp, J., Harder, J., Wehkamp, K., Wehkamp-von Meissner, B., Schlee, M., Enders, C., Sonnenborn, U., Nuding, S., Bengmark, S., Fellermann, K., Schröder, J.M. and Stange, E.F. (2004) NF- $\kappa$ B- and AP-1-mediated induction of human $\beta$ defensin- 2 in intestinal epithelial cells by Escherichia coli Nissle 1917: a novel effect of a probiotic bacterium. Infect. Immun. 72, 57505758.

43) Scharf, S., Hippenstiel, S., Flieger, A., Suttorp, N. and N'Guessan, P.D. (2010) Induction of human $\beta$-defensin-2 in pulmonary epithelial cells by Legionella pneumophila: involvement of TLR2 and TLR5, p38 MAPK, JNK, NF- $\kappa \mathrm{B}$, and AP-1. Am. J. Physiol. Lung Cell. Mol. Physiol. 298, L687-L695.

44) Albanesi, C., Fairchild, H.R., Madonna, S., Scarponi, C., De Pita, O., Leung, D.Y. and Howell, M.D. (2007) IL-4 and IL-13 negatively regulate TNF- $\alpha$ and IFN $\gamma$-induced $\beta$-defensin expression through STAT-6, suppressor of cytokine signaling (SOCS)1, and SOCS-3. J. Immunol. 179, 984-992.

45) Yang, D., Chertov, O., Bykovskaia, S.N., Chen, Q., Buffo, M.J., Shogan, J., Anderson, M., Schröder, J.M., Wang, J.M., Howard, O.M. and Oppenheim, J.J. (1999) $\beta$-defensins: linking innate and adaptive immunity through dendritic and $\mathrm{T}$ cell CCR6. Science 286, 525-528.

46) Biragyn, A., Ruffini, P.A., Leifer, C.A., Klyushnenkova, E., Shakhov, A., Chertov, O., Shirakawa, A.K., Farber, J.M., Segal, D.M., Oppenheim, J.J. and Kwak, L.W. (2002) Toll-like receptor 4-dependent activation of dendritic cells by $\beta$-defensin 2 . Science 298, 1025-1029.

47) Funderburg, N., Lederman, M.M., Feng, Z., Drage, M.G., Jadlowsky, J., Harding, C.V., Weinberg, A. and Sieg, S.F. (2007) Human $\beta$-defensin-3 activates professional antigen-presenting cells via Tolllike receptors 1 and 2. Proc. Natl. Acad. Sci. U.S.A. 104, 18631-18635.

48) Soruri, A., Grigat, J., Forssmann, U., Riggert, J. and Zwirner, J. (2007) $\beta$-Defensins chemoattract macrophages and mast cells but not lymphocytes and dendritic cells: CCR6 is not involved. Eur. J. Immunol. 37, 2474-2486.

49) Röhrl, J., Yang, D., Oppenheim, J.J. and Hehlgans, T. (2010) Human $\beta$-defensin 2 and 3 and their mouse orthologs induce chemotaxis through interaction with CCR2. J. Immunol. 184, 6688-6694.

50) Khine, A.A., Del Sorbo, L., Vaschetto, R., Voglis, S., Tullis, E., Slutsky, A.S., Downey, G.P. and Zhang, H. (2006) Human neutrophil peptides induce interleukin-8 production through the $\mathrm{P} \mathrm{Y}_{6}$ signaling pathway. Blood 107, 2936-2942.

51) Niyonsaba, F., Iwabuchi, K., Matsuda, H., Ogawa, H. and Nagaoka, I. (2002) Epithelial cell-derived human $\beta$-defensin- 2 acts as a chemotaxin for mast cells through a pertussis toxin-sensitive and phospholipase C-dependent pathway. Int. Immunol. 14, 421-426.

52) Boniotto, M., Jordan, W.J., Eskdale, J., Tossi, A.,
Antcheva, N., Crovella, S., Connell, N.D. and Gallagher, G. (2006) Human $\beta$-defensin 2 induces a vigorous cytokine response in peripheral blood mononuclear cells. Antimicrob. Agents Chemother. 50, 1433-1441.

53) Fleming, A. (1922) On a remarkable bacteriolytic element found in tissues and secretions. Proc. R. Soc. Lond., B, Biol. Sci. 93, 306-317.

54) Cole, A.M., Dewan, P. and Ganz, T. (1999) Innate antimicrobial activity of nasal secretions. Infect. Immun. 67, 3267-3275.

55) Nizet, V., Ohtake, T., Lauth, X., Trowbridge, J., Rudisill, J., Dorschner, R.A., Pestonjamasp, V., Piraino, J., Huttner, K. and Gallo, R.L. (2001) Innate antimicrobial peptide protects the skin from invasive bacterial infection. Nature 414, 454-457.

56) Wilson, C.L., Ouellette, A.J., Satchell, D.P., Ayabe, T., López-Boado, Y.S., Stratman, J.L., Hultgren, S.J., Matrisian, L.M. and Parks, W.C. (1999) Regulation of intestinal $\alpha$-defensin activation by the metalloproteinase matrilysin in innate host defense. Science 286, 113-117.

57) Salzman, N.H., Ghosh, D., Huttner, K.M., Paterson, Y. and Bevins, C.L. (2003) Protection against enteric salmonellosis in transgenic mice expressing a human intestinal defensin. Nature 422, 522-526.

58) Moser, C., Weiner, D.J., Lysenko, E., Bals, R., Weiser, J.N. and Wilson, J.M. (2002) $\beta$-Defensin 1 contributes to pulmonary innate immunity in mice. Infect. Immun. 70, 3068-3072.

59) Morrison, G., Kilanowski, F., Davidson, D. and Dorin, J. (2002) Characterization of the mouse $\beta$ defensin 1, Defb1, mutant mouse model. Infect. Immun. 70, 3053-3060.

60) Salzman, N.H., Hung, K., Haribhai, D., Chu, H., Karisson-Sjöberg, J., Amir, E., Teggatz, P., Barman, M., Hayward, M., Eastwood, D., Stoel, M., Zhou, Y., Sodergren, E., Weinstock, G.M., Bevins, C.L., Williams, C.B. and Bos, N.A. (2010) Enteric defensins are essential regulators of intestinal microbial ecology. Nat. Immunol. 11, 7683.

61) Osterhoff, C., Kirchhoff, C., Krull, N. and Ivell, R. (1994) Molecular cloning and characterization of a novel human sperm antigen (HE2) specifically expressed in the proximal epididymis. Biol. Reprod. 50, 516-525.

62) Hamil, K.G., Sivashanmugam, P., Richardson, R.T., Grossman, G., Ruben, S.M., Mohler, J.L., Petrusz, P., O'Rand, M.G., French, F.S. and Hall, S.H. (2000) HE2 $\beta$ and HE2 $\gamma$, new members of an epididymis-specific family of androgen-regulated proteins in the human. Endocrinology 141, 12451253.

63) Fröhlich, O., Po, C. and Young, L.G. (2001) Organization of the human gene encoding the epididymis-specific EP2 protein variants and its relationship to defensin genes. Biol. Reprod. 64, 1072-1079.

64) Li, P., Chan, H.C., He, B., So, S.C., Chung, Y.W., Shan, Q., Zhang, Y.D. and Zhang, Y.L. (2001) An antimicrobial peptide gene found in the male 
reproductive system of rats. Science 291, 17831785.

65) Jelinsky, S.A., Turner, T.T., Bang, H.J., Finger, J.N., Solarz, M.K., Wilson, E., Brown, E.L., Kopf, G.S. and Johnston, D.S. (2007) The rat epididymal transcriptome: comparison of segmental gene expression in the rat and mouse epididymides. Biol. Reprod. 76, 561-570.

66) Semple, C.A., Rolfe, M. and Dorin, J.R. (2003) Duplication and selection in the evolution of primate $\beta$-defensin genes. Genome Biol. 4, R31.

67) Yanagi, S., Ashitani, J., Ishimoto, H., Date, Y., Mukae, H., Chino, N. and Nakazato, M. (2005) Isolation of human $\beta$-defensin- 4 in lung tissue and its increase in lower respiratory tract infection. Respir. Res. 6, 130.

68) Otte, J.M., Neumann, H.M., Brand, S., Schrader, H., Schmidt, W.E. and Schmitz, F. (2009) Expression of $\beta$-defensin 4 is increased in human gastritis. Eur. J. Clin. Invest. 39, 126-138.

69) Harder, J., Meyer-Hoffert, U., Wehkamp, K. Schwichtenberg, L. and Schröder, J.M. (2004) Differential gene induction of human $\beta$-defensins (hBD-1, -2, -3, and -4) in keratinocytes is inhibited by retinoic acid. J. Invest. Dermatol. 123, 522529 .

70) Liu, Q., Hamil, K.G., Sivashanmugam, P., Grossman, G., Soundararajan, R., Rao, A.J., Richardson, R.T., Zhang, Y.L., O'Rand, M.G., Petrusz, P., French, F.S. and Hall, S.H. (2001) Primate epididymis-specific proteins: characterization of ESC42, a novel protein containing a trefoillike motif in monkey and human. Endocrinology 142, 4529-4539.

71) Rodríguez-Jiménez, F.J., Krause, A., Schulz, S., Forssmann, W.G., Conejo-Garcia, J.R., Schreeb, R. and Motzkus, D. (2003) Distribution of new human $\beta$-defensin genes clustered on chromosome 20 in functionally different segments of epididymis. Genomics 81, 175-183.

72) Zhou, C.X., Zhang, Y.L., Xiao, L., Zheng, M., Leung, K.M., Chan, M.Y., Lo, P.S., Tsang, L.L., Wong, H.Y., Ho, L.S., Chung, Y.W. and Chan, H.C. (2004) An epididymis-specific $\beta$-defensin is important for the initiation of sperm maturation. Nat. Cell Biol. 6, 458-464.

73) Xu, W., Zhang, X., Chen, W., Fok, K.L., Rowlands, D.K., Chui, Y.L. and Chan, H.C. (2010) Immunization with Bin1b decreases sperm motility with compromised fertility in rats. Fertil. Steril. 93, 952-958.

74) Tollner, T.L., Yudin, A.I., Tarantal, A.F., Treece, C.A., Overstreet, J.W. and Cherr, G.N. (2008) $\beta$ defensin 126 on the surface of macaque sperm mediates attachment of sperm to oviductal epithelia. Biol. Reprod. 78, 400-412.

75) Tollner, T.L., Yudin, A.I., Treece, C.A., Overstreet, J.W. and Cherr, G.N. (2008) Macaque sperm coating protein DEFB126 facilitates sperm penetration of cervical mucus. Hum. Reprod. 23, 25232534.

76) Tollner, T.L., Venners, S.A., Hollox, E.J., Yudin,
A.I., Liu, X., Tang, G., Xing, H., Kays, R.J., Lau, T., Overstreet, J.W., Xu, X., Bevins, C.L. and Cherr, G.N. (2011) A common mutation in the defensin DEFB126 causes impaired sperm function and subfertility. Sci. Transl. Med. 3, 92ra65.

77) Ashitani, J., Mukae, H., Arimura, Y., Sano, A., Tokojima, M. and Nakazato, M. (2004) High concentrations of $\alpha$-defensins in plasma and bronchoalveolar lavage fluid of patients with acute respiratory distress syndrome. Life Sci. 75, 11231134.

78) Merkel, D., Rist, W., Seither, P., Weith, A. and Lenter, M.C. (2005) Proteomic study of human bronchoalveolar lavage fluids from smokers with chronic obstructive pulmonary disease by combining surface-enhanced laser desorption/ionizationmass spectrometry profiling with mass spectrometric protein identification. Proteomics 5, 29722980.

79) Konishi, K., Gibson, K.F., Lindell, K.O., Richards, T.J., Zhang, Y., Dhir, R., Bisceglia, M., Gilbert, S., Yousem, S.A., Song, J.W., Kim, D.S. and Kaminski, N. (2009) Gene expression profiles of acute exacerbations of idiopathic pulmonary fibrosis. Am. J. Respir. Crit. Care Med. 180, 167175 .

80) Lichtenstein, A. (1991) Mechanism of mammalian cell lysis mediated by peptide defensins. Evidence for an initial alteration of the plasma membrane. J. Clin. Invest. 88, 93-100.

81) Gera, J.F. and Lichtenstein, A. (1991) Human neutrophil peptide defensins induce single strand DNA breaks in target cells. Cell. Immunol. 138, 108-120.

82) Sawicki, W. and Mystkowska, E.T. (1999) Contraceptive potential of peptide antibiotics. Lancet 353, 464-465.

83) Yamaguchi, Y., Nagase, T., Tomita, T., Nakamura, K., Fukuhara, S., Amano, T., Yamamoto, H., Ide, Y., Suzuki, M., Teramoto, S., Asano, T., Kangawa, K., Nakagata, N., Ouchi, Y. and Kurihara, H. (2007) $\beta$-defensin overexpression induces progressive muscle degeneration in mice. Am. J. Physiol. Cell Physiol. 292, C2141-C2149.

84) Bdeir, K., Higazi, A.A., Kulikovskaya, I., Christofidou-Solomidou, M., Vinogradov, S.A., Allen, T.C., Idell, S., Linzmeier, R., Ganz, T. and Cines, D.B. (2010) Neutrophil $\alpha$-defensins cause lung injury by disrupting the capillary-epithelial barrier. Am. J. Respir. Crit. Care Med. 181, 935946.

85) Chen, Q., Hakimi, M., Wu, S., Jin, Y., Cheng, B., Wang, H., Xie, G., Ganz, T., Linzmeier, R.M. and Fang, X. (2010) Increased genomic copy number of DEFA1/DEFA3 is associated with susceptibility to severe sepsis in Chinese Han population. Anesthesiology 112, 1428-1434.

86) Janssens, W., Nuytten, H., Dupont, L.J., Van Eldere, J., Vermeire, S., Lambrechts, D., Nackaerts, K., Decramer, M., Cassiman, J.J. and Cuppens, H. (2010) Genomic copy number determines functional expression of $\beta$-defensin 2 in 
airway epithelial cells and associates with chronic obstructive pulmonary disease. Am. J. Respir. Crit. Care Med. 182, 163-169.

87) Hollox, E.J., Huffmeier, U., Zeeuwen, P.L., Palla, R., Lascorz, J., Rodijk-Olthuis, D., van de Kerkhof, P.C., Traupe, H., de Jongh, G., den Heijer, M.,
Reis, A., Armour, J.A. and Schalkwijk, J. (2008) Psoriasis is associated with increased $\beta$-defensin genomic copy number. Nat. Genet. 40, 23-25.

(Received Dec. 16, 2011; accepted Feb. 21, 2012)

\section{Profile}

Yasuhiro Yamaguchi was born in 1971, and graduated from the Faculty of Medicine at the University of Tokyo in 1996. He started his career as a physician in the field of geriatric medicine and respiratory medicine. He initiated his research on the antimicrobial peptide in innate immunity in 2001. He identified novel $\beta$-defensin isoforms and elucidated their novel roles in the laboratory of Prof. Hiroki Kurihara in Kumamoto University and the laboratory of Prof. Yasuyoshi Ouchi in the University of Tokyo. He was awarded a young scientist incentive award by the Japan Foundation for Aging and Health in 2006, and an incentive award by the Japanese Respiratory Society in 2007. He has been a senior assistant professor of the Department of Geriatric Medicine, Graduate School of Medicine, the University of Tokyo since 2011.

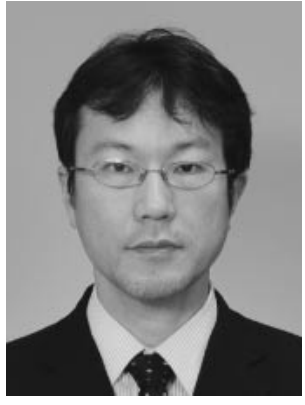

\section{Profile}

Yasuyoshi Ouchi was born in 1949, and graduated from the Faculty of Medicine at the University of Tokyo in 1973 . He was a physician scientist in the University of Tokyo hospital and in the Mitsui Memorial Hospital from 1973 to 1984. He was involved in vascular physiology research as a visiting assistant professor in the Department of Physiology and Biophysics, at the University of Tennessee from 1985 to 1986 . He became a senior assistant professor of the Department of Geriatric Medicine, Graduate School of Medicine, the University of Tokyo in 1986. He has been a professor of the Department of Geriatric Medicine, Graduate School of Medicine, the University of Tokyo since 1995. He has taken the lead in many studies in the field of geriatric medicine, cardiovascular medicine, osteoporosis, and respiratory medicine. He is an immediate past president of

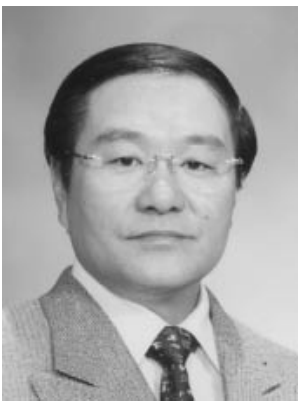
the International Association of Gerontology Asia/Oceania Region, the chairman of the Executive Committee of the Japan Geriatrics Society, and the chairman of the Executive Committee of the Japan Gerontological Society. 